\title{
Linear scleroderma en coup de sabre presenting with positional diplopia and enophthalmos
}

Figure 1 Physical examination findings
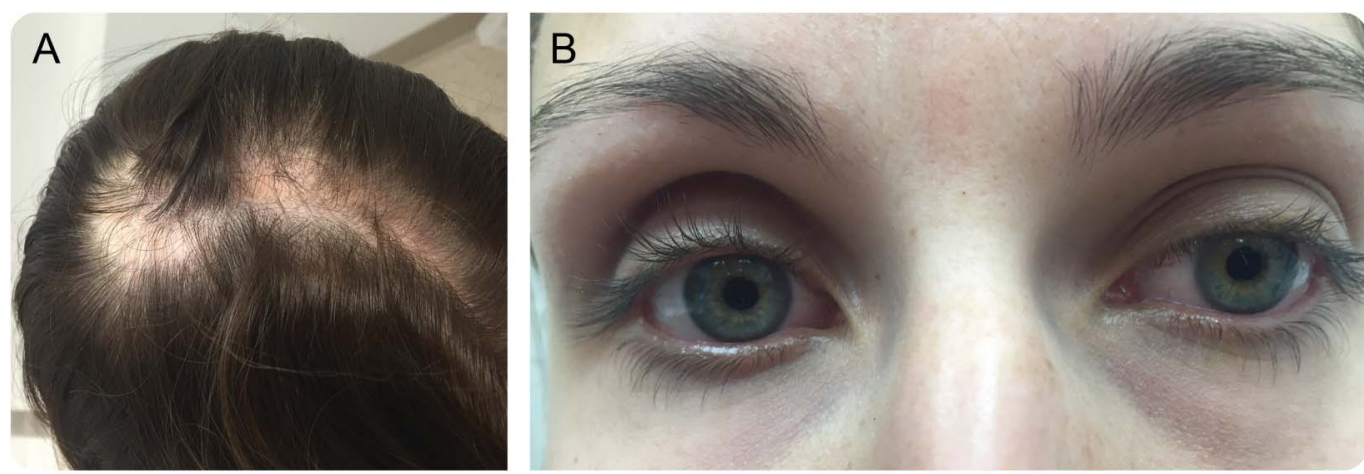

(A) Hypopigmented frontoparietal morphea right of midline. (B) Right enopthalmos due to suspected orbital fat fibrosis; also inferior lagophthalmos.
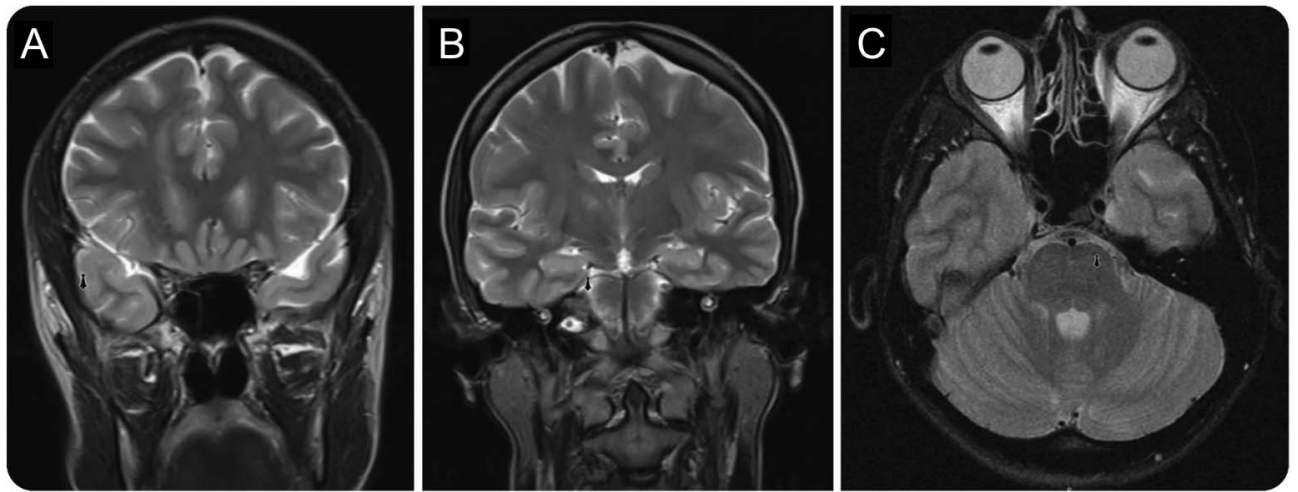

(A) Coronal T2-weighted MRI demonstrates nonenhancing hyperintensities in the right frontal lobe and (B) right thalamus. (C) Axial T2-weighted MRI orbits reveals right enophthalmos.

A 28-year-old woman with alopecia since childhood presented with 4 years of progressive intermittent diplopia and right eye getting "stuck" with upward gaze. Maddox rod test revealed a subtle intermittent right hypotropia and right enophthalmos (figure 1). Asymptomatic T2 hyperintensities were noted on MRI (figure 2). Scalp morphea was confirmed pathologically. Formal rheumatologic evaluation was otherwise unremarkable. Linear scleroderma en coup de sabre presenting as positional diplopia, unilateral enophthalmos, and focal neuroimaging findings is rare and is suspected to represent a chronic local inflammatory process. ${ }^{1,2}$ The brain lesions tend to develop adjacent to the skin atrophy. ${ }^{1}$

Lauren E. Hock, BS, Marinos Kontzialis, MD, Aimee J. Szewka, MD

From Rush University Medical Center, Chicago, IL.

Author contributions: Lauren E. Hock: analysis and interpretation of data, drafting and revising the manuscript. Marinos Kontzialis: analysis and interpretation of data, critical revision of manuscript for intellectual content. Aimee J. Szewka: study concept and design, acquisition of data, study supervision, analysis and interpretation of data, drafting and revising the manuscript. 
Study funding: No targeted funding reported.

Disclosure: The authors report no disclosures relevant to the manuscript. Go to Neurology.org for full disclosures.

Correspondence to Dr.Szzewka: Aimee_J_Szewka@rush.edu

1. Appenzeller S, Montenegro MA, Dertkigil SS, et al. Neuroimaging findings in scleroderma en coup de sabre. Neurology 2004; 62:1585-1589.

2. Suttorp-Schulten MS, Koornneef L. Linear scleroderma associated with ptosis and motility disorders. Br J Ophthalmol 1990;74: 694-695.

\section{Carry the Only Card that Helps Support the AAN-and Get a \$100 Cash Rewards Bonus!}

Apply for the BankAmericard Cash Rewards ${ }^{\mathrm{TM}}$ credit card today to start getting more cash back for the things you buy most-plus a $\$ 100$ cash rewards bonus offer! Visit AAN.com/view/CashRewards and enter priority code "VACN51."

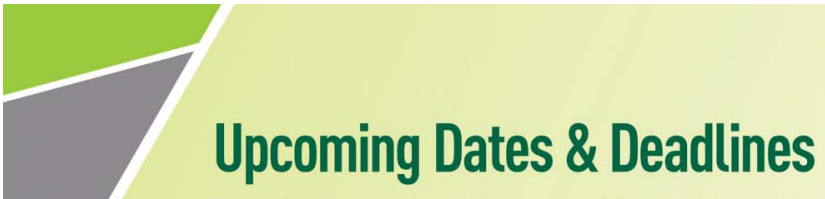

Don't miss these important dates for the 2017 AAN Annual Meeting taking place

April 22-28, 2017, in Boston, Massachusetts. Learn more at AAN.com/view/AM17.

- Abstract Submission Deadline: October 24, 2016

- Awards Application Deadline: October 26, 2016

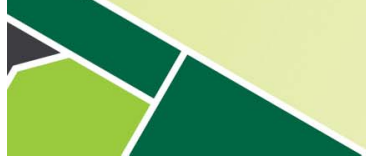

Advancing Neurology. Advancing You

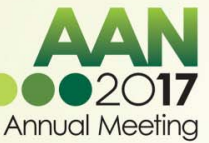

\section{BrainPAC}

BrainPAC is the American Academy of Neurology's (AAN) federal political action committee.

- Since its inception, more than 3,300 AAN members have contributed $\$ 1,900,000$ to BrainPAC.

- BrainPAC anticipates contributing \$650,000 during the 2015-2016 election cycle placing BrainPAC amongst the ranks of other major medical specialties.

- During the 2014 congressional campaign, 89 percent of candidates supported by BrainPAC won their elections.

BrainPAC supports both Democrats and Republicans who support issues important to the practice of neurology and the care of patients with neurologic conditions. US AAN members are invited to learn more at BrainPAC.org. 


\section{Neurology}

\section{Linear scleroderma en coup de sabre presenting with positional diplopia and enophthalmos}

Lauren E. Hock, Marinos Kontzialis and Aimee J. Szewka

Neurology 2016;87;1741-1742

DOI 10.1212/WNL.0000000000003239

\section{This information is current as of October 17, 2016}

\section{Updated Information \&} Services

References

Subspecialty Collections

Permissions \& Licensing

Reprints including high resolution figures, can be found at: http://n.neurology.org/content/87/16/1741.full

This article cites 2 articles, 2 of which you can access for free at: http://n.neurology.org/content/87/16/1741.full\#ref-list-1

This article, along with others on similar topics, appears in the following collection(s):

All Neuro-ophthalmology

http://n.neurology.org/cgi/collection/all_neuroophthalmology Diplopia (double vision)

http://n.neurology.org/cgi/collection/diplopia_double_vision MRI

http://n.neurology.org/cgi/collection/mri

Ocular motility

http://n.neurology.org/cgi/collection/ocular_motility

Information about reproducing this article in parts (figures,tables) or in its entirety can be found online at:

http://www.neurology.org/about/about_the_journal\#permissions

Information about ordering reprints can be found online:

http://n.neurology.org/subscribers/advertise

Neurology ${ }^{\circledR}$ is the official journal of the American Academy of Neurology. Published continuously since 1951, it is now a weekly with 48 issues per year. Copyright @ 2016 American Academy of Neurology. All rights reserved. Print ISSN: 0028-3878. Online ISSN: 1526-632X.

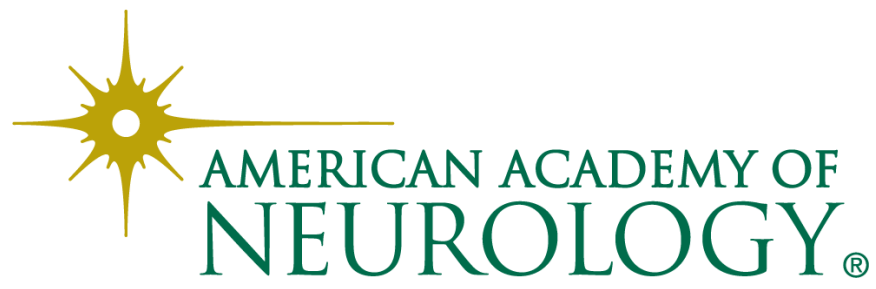

